\title{
BEHIND THE SCENES: ARCHIVAL RESEARCH ON THE THEATRE WORKS OF ALBA DE CÉSPEDES
}

\author{
DETRÁS DE ESCENA: INVESTIGACIÓN DE ARCHIVO SOBRE LAS OBRAS DE \\ TEATRO DE ALBA DE CÉSPEDES
}

Daniela Cavallaro

University of Auckland

\section{Resumen:}

Este artículo presenta los primeros resultados de la investigación de la autora sobre las dos piezas teatrales escritas y publicadas por Alba de Céspedes. Discutiendo Gli affetti di famiglia, (1952) escrita con Agostino degli Espinosa, el artículo se apoya en documentos de archivos que se encuentran entre los papeles pertenecientes a degli Espinosa. En el caso de Quaderno proibito (1961), el artículo analiza sobre todo los cambios que de Céspedes aportó a la pieza después de su estreno, para las representaciones al extranjero. A través de documentos de archivos (borradores, cartas, páginas de diario), el artículo intenta reconstruir el proceso creativo de Alba de Céspedes en sus obras teatrales, así como su actitud hacia el teatro como género de expresión creativa.

\section{Palabras clave:}

Alba de Céspedes, Agostino degli Espinosa, Gli affetti di famiglia, Quaderno proibito

\section{Abstract:}

This article presents the preliminary results of the author's archival research on Alba de Céspedes' two published plays. For Gli affetti di famiglia (1952), co-authored with Agostino degli Espinosa, it refers to documents related to the preliminary drafts of the play; for Quaderno proibito (1961), it considers in particular the changes that de Céspedes made after the play's première. The study of archival documents (drafts, letters, diary entries) helps to shed light on de Céspedes' process of creating her original theatre works and adapting her narrative work for the stage, as well as her attitude toward the theatre itself as a genre of artistic expression.

\section{Keywords:}

Alba de Céspedes, Agostino degli Espinosa, Gli affetti di famiglia, Quaderno proibito 


\section{INTRODUCTION}

The new millennium has seen a resurgence of critical attention devoted to Alba de Céspedes (1911-1997), with several scholarly works exploring her narrative and journalistic activities (Gallucci-Neremberg, 2000; Zancan, 2001; Åkerström, 2004; Morris, 2004; Zancan, 2005; Di Nicola, 2012; Muscariello, 2013; Morris 2018, to name just a few). No such attention, however, has been devoted to her theatrical production, which has remained marginal within her writings. ${ }^{1}$ And yet, such production, which consists of three staged plays and a number of unfinished, unpublished theatre projects, deserves to be brought back to the attention of the academic community.

In this article, I will present some preliminary results of my archival research on de Céspedes' plays, considering the only two that were ever published. For Gli affetti di famiglia (1952), co-authored with Agostino degli Espinosa, I will refer to documents related to the initial drafts of the play, before the play was staged; for Quaderno proibito (1961), I will consider the opposite, that is, the changes that de Céspedes made to the text after the play's première, for international stagings of the work. My hope is that the study of archival documents (drafts, letters, diary entries) will allow us to go beyond the published texts, shedding a different light on de Céspedes' process of creating her original theatre works, of adapting her narrative work for the stage, as well as her attitude toward the theatre itself as a genre of artistic expression.

\section{Gli AfFetti di famiglia (1952)}

The first play written by de Céspedes with Agostino degli Espinosa (1904-1952), ${ }^{2}$ Gli affetti di famiglia, was staged and published in 1952. No early draft of the play can be found at the Archivio Alba de Céspedes at the Fondazione Mondadori in Milan. ${ }^{3}$

However, several drafts of the drama are held among the papers belonging to degli Espinosa, housed at the Archivio Centrale dello Stato in Rome. ${ }^{4}$

The first typewritten draft to include the names of both writers is entitled "Il figlio - commedia in tre atti di Alba de Céspedes e Agostino degli Espinosa", dated April 1 1949, and labelled as "pesce d'aprile, commedia che non sarà mai scritta", suggesting

1 To date, the only play to obtain any critical attention is Quaderno proibito (1961). See de Matteis 1997 and 1998.

2 Agostino degli Espinosa was a historian and economist who in 1948 co-directed the literary magazine Mercurio with de Céspedes.

3 Archival material housed in the Archivio de Céspedes, at the Fondazione Arnoldo e Alberto Mondadori in Milan, will be indicated in these notes with AAdC, FAAM. I'm very grateful to Tiziano Chiesa, at the Fondazione Mondadori, for his support for my research.

4 Archival material housed in the Archivio degli Espinosa, at the Archivio Centrale dello Stato in Rome, will be indicated with AAdE, ACS. I'm very grateful to Crescenzo Paolo Di Martino, at the Archivio Centrale dello Stato, for his support for my research. 
that the original idea was put together without concrete plans for its development. ${ }^{5}$ However, this draft already contains the conflict of the play which will be staged three years later: Stefano learns that his former lover is expecting his baby, but now he has found true love with another woman. What does he owe his child? What does he owe himself? The conflict between Stefano and the two women (the mother of his child and his new love) becomes magnified as Stefano finds out that his biological father went through the same situation and chose love over duty. In this first draft, Stefano follows his father's example. Successive drafts, however, will modify the protagonist's final choice, condemning his father's abandonment and making of this specific case an example of generational conflict between father and son. Various titles registered in the degli Espinosa papers - such as "Per amore di Giocasta", or "Il padre è figlio" and "Edipo illegittimo" - also highlight the father-son conflict which will become central in the play.

After the composition of this first draft and until early 1952 de Céspedes spent long periods of time in the United States and Cuba (Zancan, 2011, pp. xciv-cii). Thus, some of the exchanges with degli Espinosa about the play were conducted by letter. For example, probably near the end of 1949 degli Espinosa sent a new draft of the play to de Céspedes in Washington, asking her to work with him on its revision:

\begin{abstract}
Questo non è che un abbozzo di commedia. Tuttavia, nello stenderlo, ho approfondito la trama che avevamo combinato. [...] ti prego, tieni presente che è un semplice abbozzo: tutta la struttura della commedia va riveduta, tutta la struttura delle scene va chiarita, approfondita. [...] affido il dattiloscritto al prof. Valletta che te lo farà pervenire, recandosi appunto a Washington. [...] Ho fiducia che questo canovaccio, lavorato da te, diverrà una bella cosa. ${ }^{6}$
\end{abstract}

During her stay in Italy towards the end of 1950 de Céspedes began to send out drafts of the play to theatre practitioners to gauge their interest and opinion. Guido Salvini, director of the Compagnia del Teatro Nazionale, expressed his doubts on the "interesse morale e [...] sociale" of the plot for the spectators, but favourably judged "i sentimenti dei suoi personaggi, che mi sembrano tutti vivi, e questo è il pregio maggiore della sua opera". ${ }^{7}$ Almost the opposite was the feedback received from theatre critic Silvio d'Amico, who found that although the plot concerned a case "d'un vivo interesse umano", the dialogue of the play lacked a theatrical tone: "I suoi personaggi non parlano: espongono delle tesi, con un eloquio pesante, in enunciazioni e repliche di carattere avvocatesco" ${ }^{\prime 8}$

5 AAdE, ACS, b. 8, f. 28.

6 AAdE, ACS, b. 8, f. 29.

7 Letter from Guido Salvini to Alba de Céspedes, 20 October 1950, AAdE, ACS, b. 3, f. 15.

8 Letter from Silvio d'Amico to Alba de Céspedes, 13 November 1950. Fondo Silvio d'Amico, Museo dell'Attore, Genova. 
Degli Espinosa also sent the play out to other interested parties (actor Paolo Stoppa and director Alessandro Blasetti, among others), ${ }^{9}$ at the same time updating the text according to the feedback received, as can be seen in the many drafts found in his papers. One of the major changes that can be noticed in the study of these drafts is the elimination of the character of the young pregnant woman's brother, a priest. Don Federico embodied both a defence of his sister Isabella's honor, and the voice of Catholic morality, quoting from the Bible to convince Stefano of the moral obligation to marry the mother of his child:

DON FEDERICO: La vita non si fonda su effimeri giudizi soggettivi. La vita si fonda sulla legge morale. L'individuo deve adempiere gli obblighi che, in virtù di questa legge, gli derivano oggettivamente dagli atti che compie [...] oltre Isabella, c'è suo figlio e se lei lo respinge offenderebbe Dio stesso perchè da lui, dice l'Apostolo, "prende nome ogni paternità in cielo e in terra". [...] (in tono minaccioso) Rifletta, finché è in tempo. L'Apostolo dice ancora: "Padri non provocate all'ira i vostri figliuoli". ${ }^{10}$

Several early readers of the play had expressed a negative opinion on the character of don Federico. Orazio Costa stated he did not approve of the "tono della discussione moralistica" of the play's dialogue, ${ }^{11}$ and Silvio d'Amico had been even more specific in his feedback: "Il prete non mi sembra un uomo ma una serie di sillogismi". ${ }^{12}$ In the 1951 drafts, don Federico is no longer a character in the play and several of his lines are attributed to Cecilia, Stefano's godmother and wife of his father.

Thus, when in February 1951 degli Espinosa sent a new draft of the play to Salvini, he explained that the two authors had cut some of the characters and modified others as a consequence of earlier feedback:

mi pare che l'abolizione del personaggio di don Federico abbia chiarito la drammaticità della vicenda e, nel tempo stesso, l'abbia resa più umana. [...] la correzione da Lei suggerita ha sviluppato la parte di Cecilia, sicché questa è divenuta la protagonista femminile del dramma [...] È inutile che Le dica quanto saremmo felici che il Teatro Nazionale mettesse in scena la nostra commedia. ${ }^{13}$

Despite the changes made to the play, the talks with the Teatro Nazionale did not come to fruition. Later in the same year, degli Espinosa expressed doubts over which

9 AAdE, ASC, b. 3, f. 15.

10 AAdE, ACS, b. 7, f. 28.2. The biblical quotes come from Ephesians 3:15 and 6:4.

11 Letter from Orazio Costa to Silvio d'Amico, n. d., but forwarded by d'Amico to de Céspedes on December 29, 1950. AAdE, ACS, b. 3, f. 5.

12 Letter from Silvio d'Amico to Alba de Céspedes, 13 November 1950. Fondo Silvio d'Amico, Museo dell'Attore, Genova.

13 Letter from Agostino degli Espinosa to Guido Salvini, 28 February 1951, AAdE, ASC, b. 3, f. 15. 
theatre might accept their work: "Temo che dovremo contentarci del teatro di Elsa de Giorgi a Bologna e dei Satiri a Roma". ${ }^{14}$

After all the negotiations, Gli affetti di famiglia was finally staged in one theatre only, at the Teatro delle Arti in Rome, under the direction of Ottavio Spadaro, from 24 May to 4 June 1952.

In a letter sent after the première, Alba de Céspedes reported both critical and public success: "Le critiche sono state in gran parte ottime" [... e] il pubblico ci sta dando grandi soddisfazioni". ${ }^{15}$ In reality, the critical response was not entirely positive. While some reviewers praised the play's dialogue (Prosperi, 1952), others found the case too melodramatic (Vice, 1952), and the characters too improbable (Talarico, 1952). However, the reviews would have been encouraging enough to motivate both authors to continue their work in the theatre. Such plans were tragically interrupted by Agostino degli Epinosa's suicide on 8 December 1952, which caused de Céspedes to temporarily abandon her theatrical ambitions as well. In a letter sent in April 1953, de Céspedes made an explicit connection between her work for the theatre and her coauthor's death, stating:

“dopo la scomparsa di Agostino degli Espinosa non ho avuto l'animo di occuparmi di teatro". ${ }^{16}$

\section{QUADERNO PROIBITO (1961)}

Before degli Espinosa's death, in August 1952, de Céspedes was already thinking of adapting her latest novel Quaderno proibito to the theatre, writing in her diary that she planned to "ridurre Valeria per il teatro". ${ }^{17}$ After the pause due to degli Espinosa's suicide, mentioned above, she returned to the idea of a possible theatre adaptation in letters exchanged in 1957 with Gianni Cortese, Mondadori's representative in Paris, regarding the French director Jean Mercure's interest in bringing Quaderno to the stage, with his wife actor Jandaline playing the role of the protagonist Valeria. ${ }^{18}$ Mercure and Jandaline were only the first of many French, British and Italian theatre practitioners who expressed an interest in this possible play: from directors André Barsacq and Margaret Webster to actors Susanne Flon, Madeleine Renaud, and Lilla Brignone.

14 Letter from Agostino degli Espinosa to Alba de Céspedes, 19 August 1951, AAdC, FAAM, b. 109 , f. 3.

15 Letter from Alba de Céspedes to Natalia Danesi, 27 May 1952, AAdC, FAAM, b. 5, f. 3.

16 Letter from Alba de Céspedes to Alfonso D' Alessandro, 8 April 1953, AAdC, FAAM, b. 5, f. 3.

17 Diary entry, 11 August 1952, AAdC, FAAM b. 37, f. 1.

18 Letter from Gianni Cortese to Alba de Céspedes, 2 July 1957, AAdC, FAAM, b. 10, f. 3. 
De Céspedes completed her theatre adaptation in October 1959 in French and hired literary agent Odette Arnaud to deal with the interest of international theatres and press. Despite the initial enthusiasm, however, negotiations with French and British theatres never did materialize (Zancan, 2011, pp. cxvii-cxviii). Some practitioners found Valeria's monologues - or the entire play - too long and the ending not near dramatic enough. Others mentioned that cultural differences (such as the existence of divorce or the relationship between adult children and their parents) made the plot unsuitable for an Anglo-American audience. The high number of minor characters and the narrative style of the play were given as other reasons why some directors, initially interested, ultimately decided not to stage it. ${ }^{19}$

Writing in her diary in October 1961, de Céspedes stated:

\begin{abstract}
Non sono cambiate le prospettive per la commedia, in quest'ultimo anno. Soltanto l'Italia, alla fine: tra pochi giorni (il 4) s'inizieranno le prove. Valeria sarà la Pagnani - inadatta ma brava e cara. Il regista Mario Ferrero, divenuto in breve un amico. A Parigi, dopo altre lunghe alterne vicende, dopo essere arrivati a 4 letture collegiali al Théâtre de France con Madeleine Renaud, oggi niente di fatto. [...] In Inghilterra ancora niente..$^{20}$
\end{abstract}

As de Céspedes noted, Andreina Pagnani ended up playing the role of Valeria in the staging of Quaderno proibito which premiered on 16 December 1961 at the Teatro Eliseo in Rome, and received many successful reviews for the play itself as well as for its protagonist: "Dieci con lode sul 'Quaderno proibito"', stated one reviewer (Galdieri, 1961). Soon the play was published as a book by Mondadori and in instalments by the magazine Noi donne with photos and lines from the dialogue. De Céspedes took the opportunity of the magazine format to contradict those spectators and reviewers who considered the ending of the play as praise for the protagonist Valeria's self-sacrifice. She underlined instead "il contenuto polemico" of her work, denouncing Valeria's hypocrisy and victimhood. Valeria, she explained, only redeems herself at the very end, "quando cioè Valeria, comprendendo di aver tutto sacrificato all'ipocrisia di un costume e di un mondo in putrefazione", exhorts Mirella to leave, while she remains prey to conformism and lack of courage (de Céspedes, 1962, p. 28).

The Italian success of the play was not, however, sufficient to gain a staging in France and England, as hoped. Nevertheless, Quaderno proibito was later performed in Spain (1964), Germany (1965), Greece (1969) and Turkey (1972). These international stagings are of interest not only for the success of the play which they indicate, but also because drafts of later translations of Quaderno proibito in French and Spanish kept among de

19 Letters from Odette Arnaud to Alba de Céspedes, 16 August 1960, 10 October 1961, 17 October 1961, 30 November 1961, AAdC, FAAM, b. 16, f. 1.

20 Diary entry, 14 October 1961, AAdC, FAAM, b. 37, f. 1. 
Céspedes' papers allow us to see how the writer modified her play to clarify Valeria's actions and motivations.

In fact, writing in her diary in September 1964, after receiving the Spanish translation, de Céspedes noted: “Trovato, stasera, che potrei cambiare la fine della commedia per toglierle il sospetto di conformismo". ${ }^{21}$ Thus, in addition to other changes that were probably due to the director's wish to limit the number of characters (for example, removing the character of Sandro Cantoni and the wedding scene between Riccardo and Marina), or to avoid cultural misunderstandings (the priest's visit to bless the home and the paschal lamb), de Céspedes modified the scene toward the end of the play in which Valeria declares that she has a lover and seems ready to grab her suitcase and leave the family. The only person who believes her is Marina, who states that Valeria is after all a woman like all the others. In the original text of the play, Valeria revolts against Marina's definition, reminds her family members of her life "dedicata ai miei figli, a mio marito, alla casa" (de Céspedes, 1961, p.144) and decides to remain with them, forcing Marina to share her same experience of living together with her mother-in-law for many years.

In the Spanish adaptation, on the other hand, de Céspedes added an imagined scene -with a change of lights that would suggest its sense of unreality - in which Valeria replies kindly to Marina's words, and seems to actually leave her family:

Desde este momento hasta la nueva indicación al final del próximo soliloquio de Valeria un cambio de luces debe aislar esta escena de las demás, dándole un tono de irrealidad.

Valeria se vuelve a Marina, afectuosamente, y habla como reflexionando sobre sus últimas palabras.

VALERIA: Una mujer como las demás... Es cierto, Marina. Y es precisamente para tener la posibilidad de no ser otra cosa que me marcho. (pausa breve) Por tí, en realidad... [...] Aquí no soy más que una imagen petrificada en un personaje, en un nombre: mamá. [...] la perfección sería mi revancha. Mi pecado. Serías tú la que pagaría, día por día, mi falta de valor. Mi sacrificio, como decía la abuela Adriana... ${ }^{22}$ Ese famoso sacrificio era como un monstruo que se alimentaba de vidas humanas; de mi vida, joven entonces, como la tuya.

The scene continues with Valeria interacting with her husband and her children, claiming that she had become little more than a maid for them, and that things would be better for all once she leaves:

21 Diary entry, 23 September 1964, AAdC, FAAM, b. 37, f. 1.

22 Adele in the novel and the Italian play. 
VALERIA: He comprendido que necesitamos un poco de felicidad para ser buenos... (coge su maleta) Voy a buscarlo. ${ }^{23}$

At this point, though, instead of moving toward the door to leave, Valeria would have dropped her suitcase and moved upstage to reveal her feelings, suggesting to the audience that the previous words were not real, but rather what she could have done, what she could have said:

VALERIA: (como para sí misma) Esto es lo que yo hubiera hecho si hubiera sido buena. (pausa) Preferir el amor a la venganza. Pero yo no amaba a nadie. Sólo amaba a esa imagen ejemplar de mí misma... No quería perder mi aureola, la palma del martirio, de ese martirio doméstico que día tras día había reprochado a los demás... No, yo no era buena... ${ }^{24}$

From this point on, the scene continues with everyone resuming their previous positions, and Valeria refusing Marina's label of being a woman like all the others, and blaming her family members for her self-sacrifice. With the addition of this "unreal" scene, a mirror image of the existing one, de Céspedes aimed to avoid any misunderstandings regarding Valeria's final choices. The writer further insisted to the Spanish director that the very tone of the protagonist's last lines was crucial, as Valeria reiterated her choice to stay:

Ultima battuta. Questo è importante. In Italia, è stato scritto che Valeria rimaneva per secondare il desiderio della famiglia [...]. Invece, io l'ho scritta per darle un senso minaccioso: 'Hanno voluto che restassi? E allora rimango. E vedremo' [...] Temo però che questo risultato non appaia, anche perché [...] le attrici vogliono terminare con una nota patetica, simpatica al pubblico. ${ }^{25}$

In fact, de Céspedes further asserts in her notes to the Spanish director, Valeria's last line should be pronounced "como una amenaza". ${ }^{26}$

Writing in January 1965 to Odette Arnaud about the international stagings of Quaderno proibito, de Céspedes seemed pleased with the cuts to the play suggested by the Spanish director and added that in the future any theatre company interested in the play should receive the updated version, without the marriage scene. ${ }^{27}$

Archival documents related to the play Quaderno proibito, in sum, allow us to see beyond the published text, and see how de Céspedes continued to work on the text of

23 AAdC, FAAM, b. 55, f. 1.

24 AAdC, FAAM, b. 55, f. 1.

25 AAdC, FAAM, b. 55 f. 1.

26 AAdC, FAAM, b. 55 f. 1

27 Letters from Alba de Céspedes to Odette Arnaud, 3 January and 19 January 1965. AAdC, FAAM b. 16 , f. 1 . 
this play for years - before its première, working alongside theatre practitioners who had expressed an interest in staging it; and after the Rome première and the publication of the text, to respond to requests for less characters, as well as to clarify the ending of the play and the motivations of her protagonist.

\section{Conclusion}

Letters, diary entries, and drafts of plays, found in the papers of Alba de Céspedes and of her co-author Agostino degli Espinosa, allow us to see how de Céspedes (and her co-author, for Gli affetti di famiglia), already well-known as a novelist, responded to feedback from theatre practitioners. Letters exchanged with directors, critics and theatre agents, as well as drafts of the plays from before and after their première (for Gli affetti di famiglia and Quaderno proibito respectively) grant us the opportunity to get an inside look at the process of creation of the plays themselves, going beyond the published text.

Furthermore, Alba de Céspedes' diary entries and letters reveal her ambivalent attitude toward theatre as a genre, alternating between enthusiasm and drudgery. In a letter of 1950, as she was working on Gli affetti di famiglia, de Céspedes stated: "Io sono sinceramente appassionata al teatro e credo [...] che esso sia, oggi, il miglior mezzo per parlare al pubblico. Perciò metterò tutto il mio impegno nel tentare di fare qualcosa di serio; vorrei dire, di utile" ${ }^{28}$ On the other hand, many years later, as she was working on the theatre adaptation of Quaderno proibito, de Céspedes wrote in her diary: "Il teatro, [...] temo che sia un ripiego, un raccourci, che alla fine si svela più nocivo dell'inattività stessa. In me si spiega solo per il desiderio di scrivere, essere viva con qualcosa". ${ }^{29}$ And yet, a few more years later, reporting in her diary on a play she had attended at the Théâtre de France, de Céspedes could not help but again express her passion for the theatrical genre: "Eppure, anche una sola scena di teatro, la vista sola del palcoscenico, mi rimette nell'aria del teatro, mi invoglia di tornare a scrivere per questo genere forse ormai morente, destinato alla morte" ${ }^{30}$

De Céspedes did not explain why she considered theatre a dying genre - and yet continued to write for the theatre, in 1967 adapting, with Raf Vallone, her novel $\mathrm{La}$ bambolona to the stage ${ }^{31}$ and leaving other unfinished play drafts among her papers.

28 Letter from Alba de Céspedes to Silvio d'Amico, 9 December 1950. Fondo Silvio d'Amico, Museo dell'attore, Genova.

29 Diary entry, 14 May 1959, AAdC, FAAM, b. 37, f. 1.

30 Diary entry, 22 October 1964, AAdC, FAAM, b. 37, f. 1.

31 The co-authors worked together in the Summer of 1967 (Zancan 2011: cxxviii) but then in January 1968, when she previewed the play, de Céspedes was not happy with the results. Thus, the original subtitle of the play - "commedia in due tempi di Raf Vallone e Alba de Céspedes" - was changed in "libera riduzione di Raf Vallone dal romanzo omonimo di Alba de Céspedes". Moreover, 
There is no doubt that further archival research will be necessary to delve even deeper in de Céspedes' passion and writings for the stage.

\section{WORKS CITED}

Åkerström, Ulla (2004). Tra confessione e contraddizione : uno studio sul romanzo di Alba De Céspedes dal 1949 al 1955. Roma : Aracne.

de Céspedes, Alba (1961). Quaderno proibito. Commedia in due tempi. Milano: Mondadori. de Céspedes, Alba (1962). Alba de Cespedes presenta la sua commedia. Noi donne, 17(10), 28.

de Céspedes, Alba and Agostino degli Espinosa (1952). Gli affetti di famiglia. Sipario $75,37-56$.

de Matteis, Tiberia (1997) Quaderno proibito di Alba de Céspedes: un diario in scena. Ariel, 12(1), 93-100.

de Matteis, Tiberia (1998). “Banti e de Céspedes: due narratrici prestate al teatro". In F. Angelini (ed.), Il puro e l'impuro. (121-131). Roma: Bulzoni.

Di Nicola, Laura (2012). Mercurio. Storia di una rivista 1944-1948. Milano: Il Saggiatore.

Galdieri, Michele (18 December 1961). Dieci con lode sul “Quaderno proibito”. Momento sera.

Gallucci, Carole C. and Ellen Nerenberg (eds.) (2000). Writing beyond fascism: cultural resistance in the life and works of Alba de Céspedes. Madison Fairleigh Dickinson University Press; London: Associated University Presses.

Morris, Penelope (2004). From Private to Public: Alba de Céspedes' Agony Column in 1950s Italy. Modern Italy, 9(1), 11-20.

Morris, Penelope (2018). Problems and Prescriptions: Motherhood and Mammismo in Postwar Italian Advice Columns and Fiction. In P. Morris and P. Willson (eds.), La Mamma. Interrogating a National Stereotype. 77-104. New York: Palgrave Macmillan.

Muscariello, Mariella (2013). Oltre la soglia delle apparenze: Quaderno proibito di Alba de Céspedes. In Rossella M. Riccobono (ed.), A Window on the Italian Female Modernist Subjectivity: From Neera to Laura Curino. 105-118. Newcastle upon Tyne, UK: Cambridge Scholars Publisher.

Prosperi, Giorgio (7 June 1952). Edipo uccise Laio per amore di Giocasta. La settimana Incom.

Talarico, Elio (1 June 1952). Fumetti travestiti. Il lavoro illustrato.

Vice (25 May 1952). Gli affetti di famiglia. Il Momento.

even a few years later de Céspedes was quite resolute that the play should not be staged again, writing on the text "Da non rappresentarsi più in nessun caso e da proibire nuovamente qualora ripresa (a mezzo avvocato)". AAdC, FAAM, b. 58, f. 3. 
Zancan, Marina (2011) Alba de Céspedes. Milano : Fondazione Arnoldo e Alberto Mondadori.

Zancan, Marina (2005). Alba de Céspedes. Milano: Il Saggiatore.

Zancan, Marina (2011). Cronologia. In A. de Céspedes, Romanzi. (lxiii-cxlv). Milano: Mondadori. 